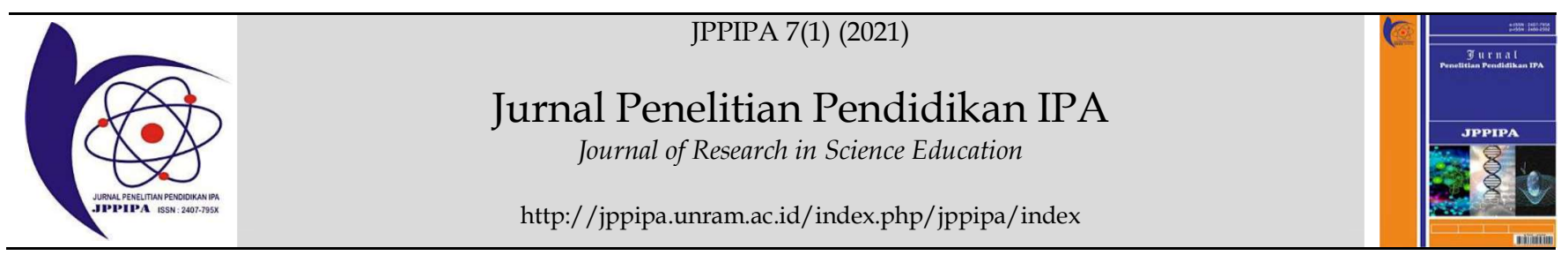

\title{
Validity of Ethnoscience Based Chemistry Learning Media Emphasizing Character Values and Conservation Behavior
}

\author{
Rizki Utari ${ }^{*}$, Yayuk Andayani 1,2,3, Lalu Rudyat Telly Savalas ${ }^{1,3}$, Yunita Arian Sani Anwar1,3 \\ ${ }^{1}$ Master of Science Education Program, University of Mataram, Indonesia \\ ${ }^{2}$ Department of Pharmacy Education, University of Mataram, Indonesia \\ ${ }^{3}$ Department of Chemistry Education, University of Mataram, Indonesia
}

DOI: $\underline{10.29303 / \text { ippipa.v7i1.469 }}$

Article Info

Received : August 22th, 2020

Revised : December 19th 2020

Accepted: December 22th 2020

\begin{abstract}
This study aims to obtain a valid chemistry learning device based on ethnoscience emphasizing character values and conservation behaviors. This study refers to the 4D model from Tiahgrajan, S. Semmel \& Semmel which was modified into three stages, namely define, design, and develop. The chemistry learning kit that has been validated by three experts consisted of ethnics-based chemistry modules, lesson plans, student worksheets, and questionnaire sheets. The validity of chemistry learning devices was analyzed using the Aiken's V formula which was consulted to the criteria in the validity table. The results showed that the developed devices were appropriate for use in learning with an individual score of each component as follows: the implementation plan of learning got a score of 0.91 (very valid), the Chemistry module got a score of 0.91 (very valid), the student worksheet got a score of 0.89 (very valid), and the poll got a score of 0.72 (valid).
\end{abstract}

Keywords: Learning tools; validity; ethnics

Citation : Utari, R., Andayani, Y., Savalas, L.R.T., \& Anwar, Y.A.S. (2020). Validity of Ethnoscience Based Chemistry Learning Media Emphasizing Character Values and Conservation Behavior. Jurnal Penelitian Pendidikan IPA. 7(1). 45-48. doi: https://doi.org/10.29303/jppipa.v7i1.469

\section{Introduction}

The combination of scientific knowledge in schools with genuine science knowledge in the community (Gondwe \& Longnecker, 2015), can make students pay more attention to environmental issues. The application of learning like this (scientific knowledge in school with genuine knowledge) can increase students' understanding of science concepts and make learning more meaningful (Okebukola, 1986), especially at a present circumstance where there are still many scientific concepts that have not been formalized in the school. The level of understanding of scientific concepts by teachers has a close relation to their professionalism in their attempts to introduce ethnics-based science material especially chemistry courses (Andayani, 2018). In an ideal situation, a teacher is required to recognize and preserve culture in daily life that can be used as a source of learning with ethnographic approaches (Wardani et al., 2013).

This ethnoscience-based learning will introduce the students with a phenomenon that is trusted by the community that can be integrated with existing scientific science material (Atmojo, 2012). This combinative learning is very important, especially at the current state where values and norms are increasingly declining. Small things that we can observe in the school environment such as littering and energy-wasting are due to the lack of awareness and sensitivity of the younger generation to protect the environment and preserve good culture previously imprinted in the society. In the culture that develops in the community, there are wise values that can be used as guidance in daily life (Wikantiyoso \& Tutuko, 2009). So that such culture needs to be integrated into learning. It was supported by Stanley \& Brickhouse (2001) who suggested that teachers should balance 
science learning in schools with traditional science knowledge in cross-cultural form as a source of learning. The thing to note is that the culture implemented must be relevant to the concept of the material to be taught.

The integration of culture is rarely considered in learning activities, so students are less familiar with their own culture. This integration is useful for instilling the character values and conservation behaviors among students. One way to present a variety of scientific content of genuine culture is by combining the referred culture or value with scientific concepts being taught. The information obtained can change the mindset of students. This change in mindset will instill character and shape good habits among students. This will have a positive impact on the environment and can build a sense of love for its culture. Therefore, students need to be provided with ethnics-based learning tools that support the formation of these attitudes (Subali et al., 2015). Teaching materials developed systematic means arranged in order making it easier for student to study (Ramdoniati et al., 2019).

This research is a preliminary study that aims to produce a valid learning tool through a series of stages of testing and validity analysis. This learning tool is based on science, that is, science that develops in societies that unconsciously has scientific value especially in chemistry. A valid ethnographic-based learning tool is expected to be used in chemical science learning which at the same time can instill the character values and environmental conservation behaviors of students (Suastra et al., 2011).

\section{Methods}

This study is a research and development (Research and Development) study. This development research procedure refers to the $4 \mathrm{D}$ model which is modified into 3 stages namely define, design, and develop. Formative evaluation is carried out at the development stage, including the validity test. Validation was carried out by 3 experts who judge the ethnoscience involved, subject matter, and media. Data analysis techniques used Aiken's V formula, namely:

$$
V=\frac{\Sigma(s)}{n(c-1)}
$$

The $\mathrm{V}$ value obtained is consulted with the validity criteria in Table 1 (Azwar, 2012).
Table 1. Scoring Criteria

\begin{tabular}{lll}
\hline No & Scoring Results & Feasibility Level \\
\hline 1 & $0.00-0.10$ & Invalid \\
2 & $0.11-0.30$ & Less valid \\
3 & $0.31-0.50$ & Fairly valid \\
4 & $0.51-0.80$ & Valid \\
5 & $0.81-1.00$ & Very Valid \\
\hline
\end{tabular}

The developed learning tool can be used in learning if it has met the valid minimum criteria, namely a scoring result of $0.51-0.80$.

\section{Results and Discussion}

Validation of the learning tool was carried out by experts on ethno science-based learning tools which included modules, lesson plans, student worksheets, and values and character conservation questionnaires. In this case, the devices are overall in the category of valid and suitable for use in learning. This is in accordance with Rochmad (2012) who states that learning devices can be categorized as feasible if they meet the criteria of content and construct validity. The following is a summary of the results of the learning device validation by expert validators.

Table 2. Validation Data of Module

\begin{tabular}{lll}
\hline Assessment Aspects & Content Validity & Criteria \\
\hline $\begin{array}{l}\text { Suitability core } \\
\text { competencies, basic }\end{array}$ & 0.91 & Very valid \\
$\begin{array}{l}\text { competencies } \\
\text { Conformity to needs }\end{array}$ & 0.89 & \\
$\begin{array}{l}\text { Material accuracy } \\
\text { Material expertise }\end{array}$ & 0.91 & Very valid \\
$\begin{array}{l}\text { Benefits in adding } \\
\text { insight }\end{array}$ & 0.83 & Very valid \\
$\begin{array}{l}\text { Supporting the } \\
\text { presentation }\end{array}$ & 0.91 & Very valid \\
$\begin{array}{l}\text { Presentation of learning } \\
\text { Ethnoscience principle }\end{array}$ & 0.86 & Very valid \\
$\begin{array}{l}\text { Ethnoscience } \\
\text { component }\end{array}$ & 1.00 & Very valid \\
Average & & Very valid \\
& 0.91 & Very valid \\
& & Very valid \\
\hline
\end{tabular}

Table 3. Validation Data of Lesson Plans

\begin{tabular}{lll}
\hline Assessment Aspects & Content Validity & Criteria \\
\hline $\begin{array}{l}\text { Formulation of learning } \\
\text { objectives }\end{array}$ & 0.93 & Very valid \\
The contents presented & 0.93 & \\
Time Allocation & 0.89 & Very valid \\
Average & 0.91 & Very valid \\
\hline
\end{tabular}

Table 4. Validation Data of Student Worksheets

\begin{tabular}{lll}
\hline Assessment Aspects & Content Validity & Criteria \\
\hline $\begin{array}{l}\text { The contents } \\
\text { presented }\end{array}$ & 0.90 & Very valid \\
Use of language & 0.89 & \\
Average & 0.89 & Very valid \\
\hline
\end{tabular}


Table 5. Validation Data of Questionnaire on the Value and Character of the Conservation

\begin{tabular}{lll}
\hline Assessment Aspects & Content Validity & Criteria \\
\hline Theory & 0.89 & Very valid \\
Constructive & 0.66 & Valid \\
Use of Language & 0.61 & Valid \\
Average & 0.72 & Valid \\
\hline
\end{tabular}

Table 2, 3, 4, and 5 shows that the developed learning tools namely modules, lesson plan, student worksheet, and questionnaires are suitable for use in learning because they have met valid criteria that reach above the average value of at least $0.51-0.80$. The learning kit was first revised according to the suggestions of the validators. Validation of the module gets a score of 0.91 which meets a very valid category. Of special note is that the ethnoscience principle and ethnoscience component scored 0.97 and 1.00 respectively that highly account for the overall validity of the module. Moreover, the module is packaged as attractive as possible so that it can help students to understand the lessons independently and can instill conservation character and behavior. The attractiveness of the module is reflected by the validator's score of 0.97 for presentation support (Table 1). The consequence of this finding is that, if teacher pays attention to local culture in learning, it will be easier for students to understand science material (Baker \& Taylor, 1995; Jegede \& Aikenhead, 1999; Michie, 2002; Erinosho, 2013). In order to obtain valid teaching materials, it is also necessary to pay attention to appearance to make it attractive to student (Nerita et al., 2018).

Second, the results of lesson plans validation were 0.91 , which falls to a very valid category. The contents of the lesson plan that have been prepared have been adjusted to the provisions of Permen No. 22 of 2016 related to the development of indicators and requirements in determining learning objectives that must meet the $\mathrm{ABCD}$ component (audience, behavior, condition, and degree). The syntax in the lesson plan is also adjusted to the model suggested in the 2013 curriculum, namely the PBL (Problem Based Learning) model, which is integrated with the ethnoscience concept.

Third, the result of student sheets validation was 0.89 which falls to a very valid category. The obtained score reflects that the student's sheets were arranged clearly, interestingly, and was complemented by ethnoscience activities that helped students to translate public science into scientific science. Additionally, the student sheets used good and correct language according to EYD (Bahasa Indonesia newest guideline), so that during the learning process, the use of the student sheets is easily understood by students (Dewi et al., 2019; Afza, 2016). Preparation of student worksheet is influenced by teachers understanding of the competency basic knowledge and skill as well the accuracy of the learning model used ( Setiadi et al., 2019).

Fourth, the results of the questionnaire validation were of 0.72 which is classified as valid. This reflects that this questionnaire can be used to see the character values and conservation behaviors that are embedded after the ethnographic-based learning process. The character values that will be instilled are discipline, responsibility, curiosity, and politeness, whereas the conservation behavior that is instilled in the culture of disposing of waste in its place, saving water, and energy. When viewed from the aspect of the questionnaire assessment, several statements have been corrected and clarified according to the validator's advice. In addition, the questionnaire indicator has been modified to suit the values and character of conservation to be instilled in the students (Sumarni, 2018).

\section{Conclusion}

Based on the results of this study, it can be concluded that the developed ethnoscience-based learning device meets the eligibility requirements both in terms of content and construct. These learning tools can be used in science learning, especially in chemistry learning.

\section{References}

Afza, A. (2016). Development of Problem Based Learning (PBL) Model Oriented Biology Learning Tools. BioConcetta Journal. 2 (1): 128-141

Andayani, Y., Hadisaputra, S., \& Hasnawati, H. (2018). Analysis of the Level of Conceptual Understanding. In the Journal of Physics: Conference Series (1095 (1), p. 012045). IOP Publishing.

Atmojo, SE, (2012). Profile of Science Process Skills and Appreciation of Students Against Tempe Craftsman Profession in Ethnographic ScienceBased Learning. JPII. 1 (2): 115-122.

Azwar, S. (2012). Reliability and Validity of Edition 4. Yogyakarta: Student Library.

Baker, D., \& Taylor, PC. (1995). The Effect of Culture on the Learning of Science in Western Countries: The Result of an Integrated Research Review. International Journal of Science Education, 17 (6), 695-704.

Dewi, SM, Gunawan, G., Susilawati, S., \& Harjono, A. (2019). The Validity of Physics Learning Devices 
Based on Generative Models Assisted by Virtual Laboratories. Journal of Physics and Technology Education. 5 (1), 162-166.

Erinsho, SY (2013). Integrating Indigenous Science with School of Science for Enhanced Learning: A Nigerian Example. International Journal for CrossDisciplinary Subjects in Education (IJCDSE), 4 (2), 1137-1143.

Gondwe, M. \& Longnecker, N. (2015). Scientific and Cultural Knowledge in Intercultural Science Education: Student Perceptions of Common Ground, 117- 147.

Jegede, O. \& Aikenhead, G. (1999). Transcending Cultural Borders: Implications for Secondary Students Attitude Toward Science. Research in Science Education, 19, 155-164.

Michie, M. (2002). Why Indigenous Science Should Be Included in the School Curriculum. Journal of Cognition and Culture, 4 (3-4), 409-450.

Nerita, S., Sri Hartati, Y., Maizeli, A., \& Afza, A. (2018). Validity Handout Based on Guided Invention Education Evaluation of Biology Learning Processes and Results. Journal of Science Education Research (JPPIPA). 4(2), 51-55. doi: 10.29303/jppipa.v5i1.148.

Okebukola, P.A.O. (1986). Influenced of Prefered Learning Style on Cooperative Learning in Science. Science Education. 70 (5), 509-517.

Ramdoniati, N. Muntari, \& Hadisaputra S. (2019). Problem Based Chemical Teaching Materials Development Learning to Improve Metacognic Skills. Journal of Science Education Research (JPPIPA). 5(1), 27-33. doi: 10.29303/jppipa.v5i1.148.

Rohmad. (2012). Design Model of Device Development and Mathematics Learning. Kreano Journal, 3 (1), 59-72.

Setiadi, D., Jufri, A.W, Ramdani, A., Jamaluddin, Bachtiar, I. (2019). Teaching Materials Development and Science Student Worksheet to Improve Science Literacy Competence for Teachers of Junior High School Science MGMP Members in Mataram City. Jurnal Pengabdian Magister Pendikan IPA (JPMPI). 2(2). Pp. 127-132.

Stanley, WB \& NW Brickhouse. (2001). The Multicultural Question Revisited. Science Education.Vol.85 (I): 35-48.

Suastra, I. W., Tika, K., \& Kariasa, N. (2011). The effectiveness of Local Culture Based Science Learning Models to Develop Basic Science Competencies And Local Wisdom Values In Junior High Schools. Research and Development Journal. 5(3), 258-273.

Subali, B., sopyan, A., \& Ellianawati, E. (2015). Developing Local Wisdom Based Science
Learning Design to Establish Positive Character in Elementary School. Indonesian Journal of Physics Education, 11(1), 1-7. https://doi.org/10.15294/jpfi.v11i1.3998.

Sumarni, W. (2018). Ethnoscience in Chemistry Learning: Principles, Development and Implementation. Semarang: Unnes Press.

Wardani, S., Kadarohman, A., \& Permanasari, A. (2013). Java Culture Internalization in Electrometry Learning Based Inquiry Laboratory Activities. Inter-Intrapersonal Intelligence. 2 (5), 417-421.

Wikantiyoso, R., \& Tutuko, P. (2009). Local Wisdom for Urban Planning and Designing to Realize Sustainable Urban architecture (1 ed). Malang: Architecture and Urban Conservation Groups. 